\title{
Internationalisation of Higher Education in Romanian National and Institutional Contexts
}

\author{
Ligia Deca, Eva Egron-Polak and Cristina Ramona Fit
}

Keywords Internationalisation - Higher education - Bologna process - Policies • Data $\cdot$ Mobility $\cdot$ Students $\cdot$ Institutions $\cdot$ Universities $\cdot$ Romania

\begin{abstract}
Abbreviations
ACBS The Agency for Students Loans and Scholarships

ANPCDEFP The National Agency for Community Programs in Education and Professional Training

ARACIS The Romanian Agency for Quality Assurance in Higher Education DS Diploma supplement label

ECTS European Credit Transfer and Accumulation System

EHEA European Higher Education Area

EUA European Universities Association

HEIs Higher Education Institutions

IAU International Association of Universities

MFF Multiannual Financial Framework

MEN Ministry of National Education

NIS National Institute for Statistics

OECD The Organisation for Economic Co-operation and Development

UEFISCDI Executive Agency for Higher Education, Research, Development and Innovation Funding
\end{abstract}

L. Deca $(\square)$

University of Luxembourg, Executive Agency for Higher Education, Research,

Development and Innovation Funding (UEFISCDI), Luxembourg City, Luxembourg

e-mail: ligia.deca@uni.lu

E. Egron-Polak

International Association of Universities (IAU), Paris, France

e-mail: e.egronpolak@iau-aiu.net

C.R. Fiț

Executive Agency for Higher Education, Research, Development and Innovation Funding

(UEFISCDI), Bucharest, Romania

e-mail: cristina.fit@uefiscdi.ro

(C) The Author(s) 2015

A. Curaj et al. (eds.), Higher Education Reforms in Romania,

DOI 10.1007/978-3-319-08054-3_7 


\section{Introduction}

\subsection{General Context and Rationale}

According to the EUA Trends VI study (2010), 'internationalisation has been identified by higher education institutions as the third, most important change driver in the past three years and is expected to move to first place within the next five years' (EUA 2010). Also, according to the third IAU Global Survey on Internationalisation, the importance of this policy area has been growing over the past several years (IAU Global Survey 2010). Furthermore, the European Commission released a Communication on the internationalisation of higher education, titled European Higher Education in the World, on 11 July 2013, that encourages both the member states and the HEIs in the European Union to develop comprehensive internationalisation strategies. Such strategies, according to the Communication, should embrace student and staff mobility, internationalisation of curricula and strategic academic partnerships as integrated elements. At EU level, funding incentives and policy support, through the EU's new Erasmus + Programme within the Multiannual Financial Framework (MFF) for 2014-2020, are promised in support of the new policy direction. The Erasmus + Programme is also one of the few EU programmes that has actually seen a substantial increase in terms of its financial support by EU.

As a member of the EHEA, Romania has committed to implementing the 'EHEA in a Global Setting' Strategy (London 2007) and the 'Mobility for Better Learning' Strategy (Bucharest 2012), which points to the need to have a strategic approach to internationalisation, both at the national and at the university level. Furthermore, Romanian Education Law 1/2011 introduced a series of reforms aimed at increasing the attractiveness of the Romanian higher education system (with provisions on what a university charter should contain regarding international partnerships, incentives for joint degrees, guaranteeing the principle of free movement of students, members of the academic staff and researchers, etc.). Looking at the rhetoric around this topic present in national level policy documents, ${ }^{1}$ the Romanian view on internationalisation seems to be highly influenced by the imbalance between incoming and outgoing mobile students and academic staff (e.g. for every incoming student, there are three outwardly mobile students), which is seen to lead to the need for increasing the attractiveness of the national higher education system.

In this context, the 'Higher Education Evidence Based Policy Making: a necessary premise for progress in Romania' project was designed to analyse the way in which five Romanian universities developed their internationalisation priorities and strategies, while also looking at how the national legal and policy contexts foster this dimension. The present article aims to outline the commonalities and differences in the approaches to internationalise their activities and develop strategies to

\footnotetext{
${ }^{1}$ See Chap. 3 for more details.
} 
this aim employed by universities with different missions, in the same national context. Furthermore, the conclusion will also touch on what specific elements of internationalisation are favoured by Romanian universities and provide some recommendations developed by the project experts' team for advancing the institutional and national activities in this field.

\subsection{Methodology}

The article relies on the research conducted on internationalisation within the 'Higher Education Evidence Based Policy Making: a necessary premise for progress in Romania' project. The analysis encompasses both the national policy environment and a review of institutional policies and practices on internationalisation.

For the institutional analysis included in the present article, the authors used the findings of a comparative mapping of both university websites and strategic documents (university strategies and operational plans) for 92 public and private Romanian universities, as well as an in-depth review of institutional policies and practices for five case study universities, based on detailed self-assessment reports and site visits carried out by teams of experts.

In the course of the desktop research phase, national legal and strategic documents were analysed, as well as official position documents of national actors and international institutions. Data was gathered and analysed from a large array of institutions, including the National Institute for Statistics (NIS), Ministry of National Education (MEN), the National Agency for Community Programs in Education and Professional Training (ANPCDEFP), the Romanian Agency for Quality Assurance in Higher Education (ARACIS), etc.

The institutional self-assessment reports were developed using the same selfassessment instrument for all institutions in the sample. This instrument was based on a version initially developed by the International Association of Universities (IAU) and revised in 2012 for the purpose of the UEFISCDI project mentioned above. This ensured its fitness for purpose and its relevance within the Romanian higher education context. The study visits included semi-structured interviews conducted by the expert panel with relevant university representatives and stakeholders (rectors, senate members, administrative staff, teachers and students). The sample of universities included institutions with different profiles (public and private, from Bucharest and other university centres). Following the study visits, a focus group with institutional representatives and experts involved in the case study reviews was organised, in order to test the conclusions of the analysis.

The direct involvement of the authors of the present article in the project, as well as their different experiences with the subject, provide a unique perspective on internationalisation policies at both national and institutional level, which contributed to anchoring the conclusions of the article in international, national and institutional realities. 


\section{Internationalisation-Theoretical Considerations and Main Trends}

\subsection{The Concept of Internationalisation}

Internationalisation has come to encompass so many meanings and activities that it proves difficult to make sure that members of a specific academic community have more or less a common understanding of what this concept may or can entail. Jane Knight describes internationalisation as "the process of integrating an international, intercultural or global dimension into the purpose, functions and delivery of postsecondary education" (Knight 2008, p. XIX). In this understanding, which is also used in the present article, it is a process with two main related components - "internationalisation at home" and "internationalisation abroad" (Knight 2008, p. 14). Internationalisation at home includes various institutional strategies and instruments to enhance students' international understanding and intercultural skills, while internationalisation abroad comprises, inter alia, cross-border mobility of students, teachers, researchers, as well as programmes, courses, and projects.

Another widely used definition of internationalisation is that employed by the OECD, according to Pricopie et al., the OECD describes internationalisation as "the totality of processes whose combined effect, planned or not, is to ensure the international dimension of higher education experience in universities and similar educational institutions" (Pricopie 2011, p. 9).

Internationalisation is, however, not an aim in itself, but a way to ensure that higher education responds to a growing need for openness and cooperation, continuously enhances its quality and responds to the increasingly global challenges (Qiang 2003, de Wit 2011).

Not only can rationales for internationalisation of higher education be quite different in their nature (political, economic, social/cultural and academic), but various stakeholders may also have different rationales for pursuing their interests in this field (IAU 2012). Rationales may change over time and are of course not mutually exclusive. An understanding of the rationales for internationalisation can also help frame different approaches that policies and institutions may adopt.

The diversification of rationales for internationalisation has both been brought about by and created new challenges for higher education systems and institutions: the decrease in funding for the educational sector, affecting countries differently; the increased competition between institutions, also caused by the growing importance of national and international rankings in categorising and comparing institutions, and which some prospective students use in making their choice for a higher education programme; the increased demand for the use of English in research and teaching and its implications for national cultural and linguistic heritage; and the increased competition among major international companies aiming to attract well prepared graduates. These are some of the leading external factors that impact on the internationalisation strategies currently being developed. At present, the top three rationales listed for internationalisation by HEIs are improving student 
preparedness for a globalized/internationalised world, internationalising the curriculum and improving academic quality, and enhancing an institution's international profile and reputation (IAU 2010).

Yet, in some parts of the world and in some institutions, perceptions regarding internationalisation have been changing in the recent past and some approaches are at times highly criticised. This is due to the fact that in some cases, internationalisation can be characterised as:

- shifting from cooperation for "capacity building" to cooperation in order to create alliances to advance in the global competition;

- shifting from an approach that offered students access to programmes unavailable to them at home, towards a focus on attracting the best and the brightest students to one's institution;

- shifting from solidarity and collaboration-based academic partnerships to "strategic partnerships linked to economic and geopolitical goals";

- a tendency for higher education institutions to put more emphasis on prestige and positioning in rankings than on providing their students with as diverse an internationalisation experience as possible. (Egron-Polak 2012)

Internationalisation of higher education is not a new concept for Romanian universities, but its (re)formulation as a comprehensive process, mainstreamed within the overall university strategy and activities is still underway. In the past two and a half decades, higher education reforms inspired by European or international developments had a negative legitimation in Romania, based on the negative impact of not implementing policies that decision-makers claimed were transferred from international levels (Wodak 2010). It is thus natural that sometimes the benefits of adopting internationalisation in a comprehensive way are not immediately obvious to institutional actors.

Clearly in its evolution, "internationalisation" has gained multiple meanings and there are various ways in which it is interpreted and pursued in different contexts around the world. Moreover, there are both positive and less positive effects and consequences of the process of internationalisation and these were taken into account when looking at internationalisation of higher education at both national and institutional level within the Romanian context.

\subsection{Internationalisation Policies in Europe: The Bologna Process and EU Policies}

\subsubsection{Internationalisation Developments in the Bologna Process}

Within the European context, internationalisation of higher education has been a major concern for policy makers and this became manifest when EHEA Ministers adopted first in 2007 the 'EHEA in a Global Setting Strategy' and in 2012 the 
'Mobility for Better Learning' Strategy. It is worth remembering that the Bologna Process started with Bologna Declaration of 1999 that is in itself a manifestation of the need, as well as joint efforts by governments, the private sector and higher education, to reform higher education in Europe toward becoming more competitive in the global knowledge economy.

It can be argued that the Bologna Process includes Europeanisation, as a form of internationalisation, as one of its main goals. From the start, this inter-governmental voluntary initiative intended to strengthen the competitiveness and attractiveness of European higher education and to foster student mobility. Conscious of the fact that the first decade of the present millennium has given rise to new challenges, the EHEA ministers, gathered at Leuven/Louvain-la-Neuve in 2009, broadly stated the issues that need to be addressed in a changing environment. One of the political goals adopted for the EHEA to be achieved by 2020 is ensuring that at least $20 \%$ of those graduating in the EHEA have had a study or training period abroad.

The 2007 'EHEA in a Global Setting Strategy' outlined the following main priorities:

- improving information on the European Higher Education Area;

- promoting European Higher Education to enhance its world-wide attractiveness and competitiveness,

- intensifying policy dialogue,

- strengthening cooperation based on partnership and

- furthering the recognition of qualifications.

Following five years of implementation, the EHEA ministers decided to deepen the initial objectives, by adopting the 2020 Mobility Strategy in Bucharest (2012). Among the very clear messages that the strategy sends, the following ministerial commitments are particularly relevant to the current analysis: develop and implement national internationalisation and mobility strategies in all EHEA countries (which include clear objectives and targets), work for better balanced mobility across the EHEA, expand mobility funding and provide a wider portability of grants and loans, improve the recognition process based on the existing Bologna Process tools, as well as the use quality assurance and transparency instruments to promote quality mobility inside and outside EHEA.

The strategy also specifies the measures that need to be adopted by higher education institutions in the EHEA. It calls for universities to build their own internationalisation strategy and to promote mobility considering their profile while involving stakeholders, particularly students, teachers, researchers and other staff.

\subsubsection{EU Policies on Internationalisation}

Since EU has always looked at internationalisation as only taking place outside of its borders, EU policies have always been circumscribed to the goal of making Europe competitive on the global scale. Higher education and research are seen as key sectors in the strategy to make Europe more able to respond to global 
challenges. As the EU Council underlined in the conclusions on the internationalisation of higher education (Council of the European Union 2010) released in May 2010: "International cooperation in higher education is an important and rewarding area which deserves support at both national and EU level" (Council of the European Union 2010). The Council also called on the European Commission, inter alia, to develop a EU international higher education strategy. The "European higher education in the world" Communication from the European Commission was therefore released on the 11 July 2013 in response to the Council conclusions of May 2010 on the internationalisation of higher education.

The Communication aims to clarify the EU approach to internationalisation of higher education. It underlines the key priorities that higher education institutions and member states should have in mind to increase their internationalisation activities and highlights the specific actions that the EU will take to support internationalisation and the next steps. A key focus of the document is the need for comprehensive internationalisation strategies at the national and institutional level that should, in the view of the European Commission, cover three main areas: promotion of international mobility for students and staff; promotion of internationalisation at home and digital learning and last, but not least, strengthening strategic cooperation, partnerships and capacity building. Detailed policy guidance is provided on how to deepen each of the three areas at national level, while remaining in sync with EU priorities. (European Commission 2013).

The EU committed to provide consistent financial support through the new programmes Erasmus + and Horizon 2020 for students, staff and researcher mobility, as well as internationalisation activities - such as joint degree programmes (master and doctoral) developed by international university consortia, strategic partnerships for cooperation and innovation and capacity-building partnerships between EU and non-EU higher education institutions.

In brief, it seems all European level policy guidelines in this field insist that the best way forward is for national authorities to provide a comprehensive policy framework for higher education institutions to pursue internationalisation.

The next section will briefly look at how internationalisation was understood in the Romanian higher education context and, based on this understanding, how its components were implemented at the national and institutional level. For the purpose of this article, internationalisation of higher education is seen as a multifaceted process, which includes, but is not limited to, partnerships and cooperation, mobility of students and staff, internationalisation of the curriculum and campus life and institutional communication and promotion. It is not restricted in geographical terms to an intra- or an extra- European outlook, and takes into account Romania's commitments as both an EHEA and EU members. These dimensions were analysed at the institutional level, as the self-assessment instrument covered these areas for all case study universities. Internationalisation of research was not considered for the purpose of this article, since internationalisation in this sector relies on a different set of national policies and international commitments (in the frame of the European Research Area) and a full account of both dimensions would have been 
too extensive for the present contribution. Nevertheless, the authors fully recognise the importance of research internationalisation in the overall national and institutional internationalisation policies.

\section{Internationalisation of Education in the Romanian Context}

\subsection{National Perspectives on Internationalisation of Higher Education}

\subsubsection{Policy Milestones and General Data Regarding Internationalisation of Higher Education in Romania}

Currently, Romania has no overall internationalisation or mobility strategy (Ulrich Teichler 2011). In the past decades however, decision-makers promoted various policy instruments. Pre-1989, Romania combined foreign affairs priorities with higher education policies and strengthened mobility and cooperation with African, Asian and South American countries. The reduced fees, special programmes and student services, as well as the promotion of Romanian higher education in those regions generated an all-time high number of foreign students enrolled in Romanian universities who represented approx. $10 \%$ of the overall student numbers in 1981, for example.

In the first decade of transition after the fall of the communist regime, Romania underwent a series of deep reforms, which enhanced the autonomy of higher education institutions while opening up to the private higher education providers. In its pre-EU accession period, Romania focused on swiftly adopting the European discourse and using the EU tools in order to prove that the national higher education system was ready, willing and able to be integrated into the European family. Chapter 18 (Education, Training and Youth) of the negotiation for Romania to become an EU member was one of the first six opened in early 2000 and among the first to be considered finalised (already in May 2000).

The Ministry of Education made a series of references to mobility and internationalisation in its 2002-2010 Strategy for the Romanian higher education system (Ministry of Education 2002-2010), such as aligning to the Bologna degree system, adoption of European Credit Transfer and Accumulation System (ECTS) and Diploma Supplement Label (DS), more participation in EU programmes-Socrates II and Leonardo da Vinci II, continued cooperation with francophone countries through AUF and the need for the Ministry to support universities in establishing more international contacts and partnerships. In the Romanian Post-accession Strategy (Ministry of National Education 2007-2012), it is stated explicitly that one of the priorities represents the contribution to the 'European knowledge-based society' by enhancing the international skills of higher education graduates. One of 
the proposed indicators for achieving this goal was the number of mobile students, staff and researchers.

The Strategy Education and Research for a Knowledge Society (2009-2015) (Presidency 2009-2015), developed by the Presidential Committee for Education mentions the need to increase the attractiveness of Romanian higher education in general and of Romanian universities in particular. Various reports on the state of Romanian higher education, published annually by the Ministry of Education re-iterate the European commitments that Romania made in the frame of the Bologna Process (such as one in five graduates to have an international experience) or within EU-related areas (participation in ERASMUS and ERASMUS MUNDUS programmes, etc.). (Ministry of National Education 2010).

Finally, the Law on National Education, adopted in January 2011, mentions for the first time the principle of free movement of the members of academic communities and indicates the rationale for introducing transparency instruments such as the university classification - an effort to make the Romanian system more readable for European partners.

After looking at the policy history on this topic, the question is whether the current policy framework is seen by universities as sufficient to help them pursue internationalisation strategies and whether the overall goals set by Romanian policy makers have been achieved or can be achieved with the current instruments.

The next section looks at the national status quo of two internationalisation components: international partnerships and student and staff mobility. The same elements will also be analysed from the institutional perspective, together with other dimensions that can only be meaningfully analysed at the institutional level, in light of university autonomy namely: internationalisation of the curriculum and campus life, institutional communication and promotion.

\subsubsection{Main International Partnerships}

The main types of international partnerships in which Romanian universities are involved are Erasmus, CEEPUS, Fulbright, DAAD, Francophone area related programmes and various bilateral agreements. According to the Ministry of National Education website there are approximately 200 bilateral collaboration documents with almost 100 partner-states in the education field (Ministry of National Education). The main partner countries with which the Romanian government has signed bilateral agreements in order to provide scholarships for the academic year 2013-2014 are: Moldova, China, Armenia, Azerbaijan, Belgium, Egypt, Greece, India, Kazakhstan, Nigeria, Poland, Russia, Korea, Serbia and Turkmenistan. The total number of partnerships in which Romania's institutions were involved either as lead partner or as partner was of 853 in 2010 (9 \% more than in 2006). It is difficult to identify the area or domains specifically covered by these partnerships, their number, or whether or not they are active, since there is no centralised data at national level on this topic. However, looking at the analysed case studies, one can say that partnerships between HEIs are mainly signed for 
mobility purposes (especially Erasmus for academic or internship mobility) or for research. In this context, it is also difficult to draw a parallel between the next chapter looking at student mobility and the current one, since it is not obvious whether there is a direct link between institutional efforts to conclude partnerships and mobility flows.

\subsubsection{Student Mobility}

During the communist regime, the number of foreign students studying in Romania began to rise. At that time, Romania was among the top 15 countries in the world in terms of hosting foreign students and providing them with academic services, with 1981 being the peak year for Romania. In the last years of the communist regime the numbers of foreign students suffered a considerably reduction (Remus Pricopie 2011). Starting with the '1990s, foreign students in Romania began having a more diverse background, since Romania signed new bilateral agreements with many countries from Europe, as well as with Canada and the USA. Furthermore, the Ministry of Education started putting into place measures specifically targeted towards the internationalisation of education by launching study programmes (in domains like medicine, political sciences, engineering, public administration) in internationally used languages such as English, German, French or Hungarian. Additionally, in 1996, Romania joined the SOCRATES Programme with an important component-Erasmus. Since 1991 the Romanian Government has continuously encouraged students from the Republic of Moldova (Basarabia) to study in Romania by offering them targeted scholarships, as part of its larger foreign policy strategy.

In terms of student mobility statistics, it is important to highlight that at the national level, Romania does not have a clear record of students who have benefited by a mobility period. There are various reports, studies and statistical series based on different definitions of mobility, but there is no centralised database with the student numbers and countries in which they experienced academic mobility. In Romania there are at least two data sets regarding mobility: one is the data set based on numbers provided by universities participating in the data collection process for the university classification and study programs ranking (published in May 2011) and the other one is the data collected by the National Institute of Statistics (NIS).

When looking at the most recent NIS available data, the total number of foreign students studying in Romania (students enrolled in Romania, Erasmus, bilateral partnerships) reached 15,391 in 2009 (1.4\% from the total number of students), most of them originating from Europe, Asia and Africa. However, when looking at the Erasmus figures, the number of incoming mobile students is three times smaller than the number of outgoing students with this program (UEFISCDI 2013). According to data collected as part of university classification process in the academic year 2009-2010, the number of incoming students in Romania was 1,359 for all levels of study, while the number of outgoing mobile students for at least 3 months was 4,768 in all levels of study. As for degree mobility, according to 
UNESCO Institute of Statistics, in 2011-2012 there were approximately 26,000 Romanian students who chose to study in other countries and 10,903 foreign students who came for an entire cycle to Romania. These figures show that the number of incoming students for degree mobility is 2.4 times lower than that of outgoing students for an entire study cycle. In this context, Romania can be seen as an exporting country in terms of student mobility, which raises concerns regarding the "brain drain" phenomenon since there is no available data concerning the number of returning students.

In 2011-2012, the top destination countries for Romanian students who chose to take a short study mobility period are France, Spain, Italy, Germany and Portugal. Regarding the choice of country for full degree mobility, students preferred Spain, Italy, UK, Denmark, the Netherlands and Sweden. Foreign students originate mostly from the Republic of Moldova (Romanian ethnics), Israel, Tunisia, France, Greece and Germany.

The highest number of student mobility is recorded at bachelor level. Language proximity and the existence of Romanian ethnic communities in certain countries seem to influence the preference of both incoming and outgoing mobile students.

\subsubsection{Academic Staff Mobility}

The ANPCDEFP report from 2012 (ANPCDEFP 2012) concludes that there were 1268 outgoing mobile staff members with teaching assignments and 709 staff members that were mobile for training purposes in the academic year 2011-2012. According to 2012 ANPCDEFP report, the estimated participation rate of teachers to Erasmus mobility is $7 \%$ and the main countries preferred by academic staff for mobility periods abroad were France, Italy, Hungary, Germany and Spain.

As for the incoming members of the academic staff, available data has been identified only for the undergraduate cycle and for the academic year 2009-2010. The number of teaching staff and scientific research staff attracted from universities abroad for teaching activities (for a period corresponding to at least one semester) was 554 in 2010, according to the data from the Romanian universities' classification process. No central overview concerning the origin countries was identified at national level.

As staff mobility is a central multiplication factor for enhancing student mobility, as well as a central objective for increasing the attractiveness of the Romanian higher education system, the current low system performance both in terms of sending academic staff abroad and attracting international members of staff to Romania can be seen as another area in need of immediate attention in order to enhance internationalisation of higher education in Romania. 


\subsection{Internationalisation of Higher Education at the University Level}

When analysing the internationalisation of universities, six particular aspects have been looked at: strategic and institutional framework, partnerships and cooperation, student and staff mobility, internationalisation of the curriculum and campus life, as well as institutional communication and promotion. As mentioned before, these components were selected based on the self-assessment instrument used for the case studies and the areas which were most mentioned by sample universities when talking about internationalisation of higher education.

\subsubsection{Comparative Analysis of the Strategic Institutional Framework}

Following a qualitative analysis of strategies and operational plans from 92 public and private universities in Romania, it was found that:

- at least 15 universities have not yet established a department of international relations in the organisational chart or the department was not identified on the official websites;

- 43 higher education institutions have either vague or no information on institutional strategies for internationalisation and mobility;

- an additional 30 universities mention internationalisation of education, mobility and partnerships in general terms, but there is no comprehensive strategy with concrete targets;

- only 19, about one fifth of the universities had set detailed objectives and concrete references in regard to the internationalisation of higher education.

The case of Romania was described by Ferencz and Wächter (2012) as an unusual one: the policy framework 'evolved' from a very well-articulated strategy with regard to internationalisation and mobility in the '1970s to virtually no overall strategy. Policy-makers claim that this is a consequence of institutional autonomy, but clear and increasingly numerous examples of countries that successfully combine national level policy with institutional strategies developed by independent and autonomous institutions make this claim highly questionable.

Moreover, based on the five Romanian university case studies, it can be concluded that Romanian universities are primarily focused on mobility and institutional partnerships, while other aspects of internationalisation are dealt with in a more ad hoc manner. When questioned about their main goals related to internationalisation of education, most case study universities indicated: the increase of incoming and outgoing mobility for students and academic staff, the establishment or development of more international partnerships, increasing and diversifying the number of courses and programmes taught in foreign languages and the increase of cooperation within university networks. 
However, there is a discrepancy between what institutions declare as their main goals and what receives focus and appropriate support. None of the case study institutions had a specific budget for internationalisation activities and only one university from the case study institutions presented a concrete institutional strategy for internationalisation to the experts' panel. The others stated that they were in the process of developing one.

\subsubsection{Partnerships and Cooperation}

Although one of the main internationalisation goals of Romanian universities is increasing the number of institutional partnerships, their focus seems to be the quantitative increase of collaborations with other universities and not the strategic pursuit of active and sustainable long-term partnerships. This conclusions stems from the fact that more than half of the case study universities' partnerships are inactive or only partially active. Universities admitted that they see no need to end the inactive partnerships; the advantages of prestige, for example, of keeping them on their lists outweighed any disadvantage that could have been caused by retaining inactive partnerships to either themselves or the involved HEIs partners. Moreover, several institutions expressed their hope to see these collaboration revived in the next future. Also, when asked about the existence of strategic partnerships or regions with which they want to collaborate, most universities admitted that they do not have strategic areas specifically targeted for new collaborations.

Most of the institutions collaborate with universities and organisations from Europe and some of them are prioritising cooperation with Asia and China, in particular. The most common rationale for developing new partnerships is the desire to be part of strong networks or to carry forward individual connections of academic staff members. Other motivational factors for developing partnerships, as reported by universities (UEFISCDI 2013) include the need for international visibility within the professional community and the rewards arising from the ongoing dialogue with partners which showed that there are mutual elements to be learnt and shared on teaching and research in order to fulfil a common goal (training human resources, developing practical knowledge and skills). Few institutions report having discussions about the value and importance of deepening the existing partnerships, in contrast to the general drive for an increasing number of partnerships and cooperation. Where deepening existing cooperation is discussed, the focus is on developing joint and double degree programmes, international conferences or other activities in collaboration with their international partners.

\subsubsection{International Students, Faculty and Staff Mobility}

When analysing mobility trends, the case study universities pointed to the small numbers of incoming students and academic staff, which they perceived as a sign of the need to focus more on measures making the university more attractive. For most 
universities, the number of outgoing students or academic staff is (significantly) higher, and only a few HEIs manage to achieve balanced inward - outward mobility flows. According to the university case study reports (UEFISCDI 2013) the percentage of international foreign students ranged from 0.5 to $4 \%$ of the total student population for the 2012-2013 academic year. Most frequently these foreign students were enrolled via Erasmus programme or inter-institutional agreements and were at Bachelor level. Although in most cases, universities indicated that they have specific targets for incoming and outgoing students, these targets did not seem to be officially adopted by the institutions since they did not presented any official document.

The analysis highlighted that although universities would like to increase the number of incoming foreign students, the vast majority do not have a coherent strategy in place that could include advertising the institution's academic programmes, foreign language /joint degrees programmes or communicating its unique selling points. For example, there was more willingness to attract students from Asia or non-EU countries, since there is no legal provision regarding the maximum tuition fee limit, and thus this is seen as a potentially important source of income. National policy seems to also influence the preferences of universities for students originating from the Republic of Moldova, since specific administrative and financial conditions are offered by the Romanian state.

In terms of outgoing mobility, universities report having as a goal the increase in the number of home students going abroad. It was recognised that there are still several issues making outgoing mobility a difficult endeavour in some cases. These include recognition of the academic credits earned upon return and the lack of financial support, since the Erasmus scholarships were considered to be too low to cover all the expenses incurred. Top country destinations for Romanian students are France, Italy and Germany and outward ERASMUS mobility seems to take place mainly at the Bachelor level, similarly as in the case of incoming mobility.

No specific priority regions for outgoing mobility were identified in the case study sample. Apart from European destinations and depending on the existing partnerships and university profiles, China and other Asian countries are certainly becoming part of the institutional leadership focus, as in other parts of the world.

The obstacles for incoming mobility indicated by the interviewed students and academic staff are the language barrier, visa issues, recognition of foreign credits or diplomas for both incoming and outgoing mobility. Specifically for the outgoing students the low financial support constitutes a significant obstacle. Financial limitations also take their toll in making it more difficult for institutions to pursue comprehensive internationalisation strategies, especially with the current restraints at national level. ${ }^{2}$ There is one notable and important exception in terms of

\footnotetext{
2 Due to economic crises, the Romanian government only allows hiring 1 new staff member for every 7 that leave public institutions. Legislation to this effect was released in 2010 and all positions were partially unlocked in 2013. Law 69/2010, art. 10, alin. (6), letter c).
} 
financing international activities, as most institutions provide funding for academic staff to participate in international conferences and some even provide financial incentives for those who publish articles in international journals.

\subsubsection{Institutional Communication and Promotion}

When it comes to the issue of communication within and outside the university concerning internationalisation, it was noted that most universities do not have a full-fledged communication strategy in place and relatively few methods (such as official website, posters, Erasmus brochures, newsletters or monthly meetings with students or academic staff) are being used in order to advertise programmes and opportunities or to disseminate information related to their own international activities. Few universities organise an "Erasmus Day", "International Days" or similar events every year meant to advertise mobility programs and international collaboration. There are also universities where no information on promoting their programmes to foreign students is available on their websites.

When analysing the websites of the 92 Romanian universities, $63 \%$ did not have the website fully available in at least one language of international circulation. However, the members of the academic community did not raise this issue during the site visits, although international attractiveness of institutions is high on the agenda for all sample universities.

The communication between institutional leadership and the academic staff was considered by some of those interviewed as rather insufficient in regards to the internationalisation process. Opinions about internationalisation of higher education differ between the senior representatives and academic staff members. There are cases when the senior management does not pay as much attention to the subject as the academic staff considers necessary and vice versa, the representatives of management or the Department for International Relations reported that when they wish to develop specific activities that can only be undertaken with support from the academic and administrative staff, the support is not available.

For most of the visited institutions, academic staff members reported having no autonomy to pursue international activities. They can make proposals related to measures and activities that are subsequently discussed and analysed by the Council of Administration. Should such proposals be validated, actions are taken for their implementation. The most common method for internal communication are monthly meetings between senior administrators and faculty members also including, in several cases, student representatives. Since no institutional strategies for internationalisation were identified in most case study universities, this makes initiatives in the area quite time uncertain and time-consuming for those who initiate them, unless they are among the university leadership representatives. 


\subsubsection{Internationalisation of the Curriculum and Campus Life}

When discussing the internationalisation of the curriculum and campus life in Romanian universities, the interviewees pointed to problems such as the lack of a shared understanding of the concept of internationalisation in the academic community, poor English language skills among the academic and administrative staff, academic courses not being harmonised with international trends and new research and course materials not being adapted or translated in the language of instruction, when the programme is available in a foreign language. A common concern was the relative lack of foreign language abilities amongst administration and to a lesser extent within the members of the teaching staff.

International orientation of the curricula was seen differently from one institution to the next. Some of the case study institutions declared that all of their programmes were international, whilst others declared that $30 \%$ or less of their programmes had an international orientation. None of institutions taking part in the project pointed to a set of specific learning outcomes that were identified, monitored and evaluated as part of an international outlook of the curricula.

The majority of the case study institutions had a small number (four or less) of undergraduate programmes taught in English . Some also had subjects available in French, German and Italian. Almost all institutions indicated that their students were required to take foreign language courses as part of their study programme, with the majority also noting that the ability to use at least one foreign language was a precondition for graduation. Foreign language classes for disciplinary knowledge, in particular English, were commonly available to students, as well as extracurricular foreign language lessons. However, most institutions did not offer foreign language training to members of the academic and non-academic staff. In all cases the number of incoming foreign teachers was $1 \%$ or less, with some institutions stating that they had no foreign staff at all. In universities where international faculty members were present, they were provided with Romanian language training and/or community activities designed to make their integration into the university life easier.

Some of the case study institutions reported good cooperation with student organisations, which actively contributed to their international efforts. These organisations bring added value to the university by preparing specific events or activities to improve integration of foreign students or reintegrate domestic ones into the academic environment. At campus level, most foreign students share dormitories with Romanian students, which also contributes to the overall student integration process. Additionally, all institutions mentioned that they had organised a number of international conferences in the past year, either at faculty or institutional level, as a vector for international visibility. 


\section{Conclusions-Internationalisation of Universities "Where to" for Romania?}

Romania is a country where internationalisation of higher education has had an interesting history, linked to a set of specific historical economic and foreign policies in the 1970-1980s, as well as with the European integration processes in the last two decades. Its linguistic affinities also influence policies and developments in this domain as exemplified by the links with other Francophone countries which are naturally prioritised. According to the existing data, Romania suffers from the brain drain phenomenon, especially in certain specific disciplines (medical studies, IT etc.) and this impacts on the perceptions and policy priorities of internationalisation.

Despite this context and the overall preoccupation with internationalisation at both state and institutional levels, Romania does not have a national strategy regarding internationalisation of higher education, nor do current higher education policy documents include clear priorities for this process, even though internationalisation is mentioned as a national priority of the higher education system in general terms. In addition, there is a chronic lack of available data regarding some of the key indicators of internationalisation of higher education, even in areas where Romania provides regular reports to European bodies, such as mobility of students and staff. The only policy, which stands out in terms of coherence, support and cooperation among governmental actors, is that referring to ethnic Romanians.

In the absence of a coherent national policy on internationalisation, the ways and means in which universities have pursued internationalisation differ widely, highly influenced by their mission and overall capacity. There is no shared understanding of this process and its importance for the future of higher education in Romania beyond a relatively small group of higher education leaders and academics.

Romania does not have a comprehensive overview of country-level bilateral or multilateral cooperation partnerships; there is no comprehensive database regarding the number of mobile students and academic staff, their country of origin or other relevant data. The perception of the participants in the focus group meetings was that the efforts of departments and agencies such as MEN, MAE, CNRED, ANPCDEFP, UEFISCDI, ACBS are largely un-coordinated and disconnected, and that this might hamper rather than facilitate institutional level internationalisation efforts, as well as the development of national level operational goals, plans and programmes.

Based on both the analysis of strategic documents for the 92 institutions, as well as on the conclusions of the study visits, it became obvious that a significant number of Romanian universities do not have internationalisation strategies nor clear references to internationalisation in their overall strategies, although they recognise the importance of the process. This might also be linked to the lack of a national debate about the concept and the potential benefits of a strategic national wide approach. Furthermore, there is an uneven understanding among the universities about the ways in which internationalisation can be an instrument to improve quality, respond to local and international needs and serve other academic and socio-economic goals. Thus the general approach to internationalisation is rather ad 
hoc, with most institutions (and much of the discussion) focusing on mobility and institutional partnerships, rather than taking a more comprehensive view that encompasses, for example, internationalisation of curricula, recognition matters and building links between international research collaboration and other international initiatives.

The national tendency to point to the lack of attractiveness of the Romanian HE system as a key obstacle to increased internationalisation seems to be reflected in the internationalization goals adopted by Romanian institutions. These are mainly linked to attracting more foreign (preferably non-EU/EEA) fee paying students and to increasing the number of inter-institutional partnerships, as it is in these areas that the issue of attractiveness has the greatest impact. These difficulties are compounded by the fact that there is a trend, whenever possible, to pursue institutional partnerships only with well renowned universities that can bring institutional prestige and many are based on personal connections of some members of the academic staff, even though many of them become inactive quite soon after they are initiated.

Mobility imbalances are evident for the analysed universities and they fully reflect the national situation. Universities are mainly focusing on attracting students from abroad, including fee-paying third country foreign students. In the context of scarce financial resources, it appears that a more commercial approach to student mobility is becoming predominant, reducing the focus on other internationalisation aspects. Current legal provisions are also seen to be hindering university autonomy to pursue internationalisation policies (e.g. hiring international staff) especially in the absence of a strategy in this field at the national level. ${ }^{3}$

Other barriers to internationalisation which stood out in the analysis of both national and institutional realities were: the instability and incoherence of the education legislation which prevents institutions from planning and executing their internationalisation strategy, administrative bottle necks (visa regulations), the lack of sufficient foreign language proficiency of both academic and administrative staff, academic recognition issues which mostly hamper student mobility and inadequate information and promotion tools, including university websites not available in other languages. Generally speaking, communication and intra-institutional collaboration needs to be strengthened to bring about better top-down and bottom-up coordination, which appeared to be lacking according to the research results.

The way in which internationalisation efforts are financed was unclear at both national and institutional level. None of the case study institutions had a special fund for internationalisation activities. And since there is no strategic document on this topic at national level, it is hard to quantify the resources that may be allocated by the state for different programmes.

\footnotetext{
${ }^{3}$ Under the agreement of the Romanian government with the International Monetary Fund, Romanian public institutions have frozen the hiring processes with the possibility of hiring one person for every seven persons that leave the institutional staff, thus making it difficult to make progress in terms of attracting new staff at the administrative level.
} 
Notwithstanding all these challenges, unique selling points and strengths of the Romanian universities were also identified during this study. First, some programmes offered are renowned for their quality and recognition abroad. These include the international programmes in medicine and dentistry, archaeology, IT, maritime studies or foreign languages. These programmes have very good infrastructure and for the most part, graduates enjoy high levels of employability. Secondly, several universities from the sample were proactive in developing partnerships with important companies (such as Microsoft, NYK, Siemens etc.), in order to provide internships for students and adapt the curricula to the labour market, while also taking into account the European and international trends. Furthermore, the geographical position of Romania offers possibilities for different institutional partnerships, strategic research and scientific international projects and exchanges. Good university facilities, inexpensive student accommodations and low cost of living in comparison with other European countries are also strengths that the Romanian higher education institutions have identified during this study.

Although universities are aware of their strengths, unique selling points and weaknesses, their internationalisation approaches appear not to focus on developing their potential or on finding ways to diminish their shortcomings as well as they could. The strategies used by universities are mostly reactive to immediate opportunities and existing European or national initiatives and less targeted to the specific profile and mission of the institution. They are also largely focused on a very narrow slice of the internationalisation process, somewhat disconnected from the pursuit of the overall institutional goals.

Perhaps one general conclusion that can be drawn from this study and the discussions with numerous Romanian stakeholders is that if Romanian higher education institutions, and the system more generally, is to become more internationally open and strengthen its participation in the internationalisation process, it must adopt a more coherent and deliberate approach at the national level, since this will facilitate the development of more proactive internationalisation strategies at the institutional level as well. Developing such a clear national policy, accompanied by measures and support, including financial support, would go a long way to overcoming the significant hurdles that stand in the way of various internationalisation goals. Even if universities were to identify clear goals and establish their own internationalisation strategies to reach them, these hurdles include the fragmented legal and institutional framework, and internally, the lack of common understanding of the rationale for internationalisation within the academic communities and the top-down methods used in pursuing its goals. The combination of mutually reinforcing internationalisation strategies at national and institutional levels may not be a panacea to overcome all obstacles but their development can be an important agenda setting and highly mobilizing process. The new set of EU programmes under the Erasmus + umbrella should also encourage, inter alia, the setting-up of joint degrees or the pursuit of strategic partnerships, and the grant applications are likely to be more successful and more pertinent if they can be based on existing national and institutional internationalisation policies. 
Thus future work at both national and institutional level is needed and could be tremendously beneficial, especially if it takes as its starting point a real examination of the rationale(s) for internationalisation in the specific national and institutional contexts, includes the setting of realistic goals, the identification of implementation actions, the commitment of financial and policy supports and mechanisms to monitor what is happening in this field in Europe and while also paying attention to international trends. Internationalisation is a continuously evolving concept, so universities need to engage in continuous analysing of their approaches, in accordance with their vision and targeted objectives. Based on the institutional analysis, as well as on Romania's strategic interests and strengths, a national policy framework could effectively support internationalisation of Romanian higher education, not as a goal in itself, but as a way to enhance quality higher education for the Romanian society.

Open Access This chapter is distributed under the terms of the Creative Commons Attribution Noncommercial License, which permits any noncommercial use, distribution, and reproduction in any medium, provided the original author(s) and source are credited.

\section{References}

ANPCDEFP. (2012). ANPCDEFP report regarding the implementation of the long-life learning program. http://www.anpcdefp.ro/userfiles/Raport_2012.pdf. Bucharest, Romania.

Basarabia. (n.d.). http://en.wikipedia.org/wiki/Bessarabia. Retrieved from http://en.wikipedia.org/ wiki.

Council of the European Union. (2010, May 11). http://www.consilium.europa.eu/uedocs/cms Data/docs/pressdata/en/educ/114378.pdf. Brussels.

De Wit, H. (2011). Trends, issues and challenges in internationalisation of higher education. Amsterdam: CAREM.

Egron-Polak, E. (2012). Higher education internationalisation: Seeking a new balance of values. Trends \& Insights for International Education Leaders, pp. 1-2.

EUA. (2010). Trends VI.

European Commission. (2013, July 11). http://ec.europa.eu/education/higher-education/doc/ com499_en.pdf. Brussels.

Ferencz, I., Wachter, B. (2012). European and national policies for academic mobility, ACA papers on International Cooperation in Education.

IAU. (2010). Internationalisation of higher education: Internationalisation of higher education: Global trends regional perspectives. Paris.

IAU. (2012). Affirming Academic value in Internationalisation of higher education: a call for action. Paris, http://www.iau-aiu.net/content/affirming-academic-values-internationalizationhigher-education-call-action.

Institutional case studies reports, 1-5 (May-September 2013).

Knight, J. (2008). Higher education in Turmoil. The changing world of internationalisation. Rotterdam: Sense Publishers.

Ministry of Education. (2002-2010). http://administraresite.edu.ro/index.php/articles/2884. Bucharest.

Ministry of National Education. (2007-2012). http://administraresite.edu.ro/index.php/articles/ 7737. Bucharest. 
Ministry of National Education. (2010). http://www.edu.ro/index.php/articles/15128. Retrieved from http://www.edu.ro/.

Ministry of National Education. (n.d.). http://www.edu.ro/index.php/articles/c27. Retrieved from http://www.edu.ro.

Presidency. (2009-2015). http://www.presidency.ro/static/ordine/COMISIA_EDUCATIE/ EDUCATION_AND_RESEARCH_FOR_A_KNOWLEDGE_SOCIETY.pdf. Retrieved from http://www.presidency.ro.

Pricopie, R. Z. (2011). Internationalisation in higher education. Bucharest.

Qiang, Z. (2003). Internationalisation of higher education: Towards a conceptual framework. Policy Futures in Education, 1(2), 250.

UEFISCDI. (2013). Internationalisation of higher education in Romania. Bucharest. http://www. politici-edu.ro/wp-content/uploads/2013/10/Internationalization-of-HE-in-Romania.pdf.

Ulrich Teichler, I. F. (2011, June). Mapping mobility in European higher education, Volume I: Overview and trends. http://ec.europa.eu/education/more-information/doc/2011/aca_en.pdf. Brussels.

Wodak, R. F. (2010). Recontextualizing European higher education policies: the cases of Austria and Romania. Critical Discourse Studies, pp. 19-40.

\section{Legal Documents}

National Education Law no. 1/2011.

Ministerial Ordinance no. 3359MD/11 March 2013.

National Ministry of Education Ordinance no. 6.000/2012.

\section{Data Used}

Data from the data collection process conducted in 2011 in order to assess and classify universities and study programs http://uefiscdi.gov.ro/articole/2535/Clasificare-universitati-si-ierarhizareprograme-de-studii.html.

Data from ANPCDEFP Reports from the official website.

Data from the National Institute for Statistics (NIS), the "Statistical annual reports on higher education" and NIS communication from the official website.

Data from the Ministry of National Education, available in 2013.

Data from ARACIS.

Data from UNESCO Institute of Statistics. 